УДК $39+82-94$

DOI: $10.33876 / 2311-0546 / 2021-53-1 / 9-23$

(C) В.В. Карлов

\title{
Ю.В. БРОМЛЕЙ И «БРОМЛЕЕВСКИЙ ПЕРИОД» ОТЕЧЕСТВЕННОЙ ЭТНОЛОГИИ
}

\begin{abstract}
Статья посвящена столетию со дня рождения академика Юлиана Владимировича Бромлея, который более 20 лет возглавлял академический Институт этнографии им. Н.Н. Миклухо-Маклая. В ичелях адекватной оченки периода в истории отечественной этнологии, когда ее развитием руководил Ю.В. Бромлей, предпринят анализ состояния этнографической науки и первоочередных задач, стоявиих перед ней к моменту прихода ученого на пост директора института. Среди назревших проблем в первую очередь выделяется важность изучения этнографической современности, а также необходимость обновления теоретико-методологической базы этнографии. Ведущчие специиалисты - этнографы понимали серьезность и масштаб этих задач, однако методы их решения не были выработаны. В статье дана оченка личного вклада академика в развитие науки в СССР, а также всего периода 1960-1980 годов в отечественной этнологии. Анализируются предложенная Ю.В. Бромлеем теория этноса, разработанные с его участием категориальный аппарат этнологической науки и методологические подходы к изучению этнографической современности. $B$ этих областях этнологического знания в период руководства Ю.В. Бромлея Институтом этнографии были достигнуты серьезные и позитивные сдвиги. Автор высказывает мнение о том, что «бромлеевское время» было весьма плодотворным периодом в истории развития этнологии в СССР.
\end{abstract}

Ключевые слова: Ю.В. Бромлей, теория этноса, этнография современности, история этнологии

Ссылка при цитировании: Карлов В.В. Ю.В. Бромлей и «бромлеевский период» отечественной этнологии // Вестник антропологии, 2021. № 1 (53). С. 9-23

21 февраля 2021 г. исполнилось 100 лет со дня рождения Юлиана Владимировича Бромлея - академика, историка и этнолога, ученого, более двух десятилетий возглавлявшего Институт этнографии АН СССР имени Н.Н. Миклухо-Маклая (ныне Институт этнологии и антропологии РАН) - головное научное учреждение этнологов страны. Уже 30 с лишним лет как он ушел из жизни. За это время многое изменилось и в науке, которой он посвятил большую часть жизни, и в стране, и мире. Страны, которой он верой и правдой служил, не стало. Наука о народах существенно сменила исследовательские парадигмы и подходы, долго представлявшиеся основательно отработанными и принятыми научным сообществом. Сейчас мы находимся в том состоянии «переходности», когда новое еще не вполне утвердилось, а старое

Карлов Виктор Владимирович - д.и.н., профессор кафедры этнологии исторического факультета, Московский государственный университет им. М.В. Ломоносова (119991 Москва, Ломоносовский просп., д. 27). Эл. почта: vikarlov@mail.ru 
не окончательно утратило наработанные позиции. В такое время тем более совсем не лишне еще раз взвесить то, что было привнесено в развитие профессиональной этнологии 1960-1980-е годы, когда этим процессом в масштабе страны руководил Ю.В. Бромлей и возглавляемый им институт.

Подобная оценка вклада Ю.В. Бромлея в науку после его смерти неоднократно высказывалась в научной литературе и периодике, но во многих работах на эту тему преобладало сопоставление «бромлеевского периода» с новыми подходами, активно внедряемыми в отечественное «народоведение» с 1990-х гг. в русле противоборства «примордиализма» и «конструктивизма». (Тишков 2020). Не оспаривая правомерность такого сопоставления, со своей стороны выскажу мнение о том, что для адекватной оценки этого периода в истории нашей науки больше подходит анализ проблем этнологического знания накануне прихода к руководству Институтом этнографии нового директора в 1966 г., и тех перемен, которые за этим последовали. Такое сопоставление, конечно, тоже проводилось (Губогло 2016; Чешко 2016). Однако мне хотелось бы остановиться на характеристике того времени и его воздействия на науку более подробно.

Но сначала будет уместно привести краткие сведения о жизненном и научном пути юбиляра. С одной стороны, то, что Юлиан Владимирович стал историком, как бы вполне естественно: он был сыном известного историка В.С. Сергеева, профессора МГУ им. М.В. Ломоносова и заведующего кафедрой античной истории, мать Н.Н. Бромлей тоже работала в МГУ, где преподавала английский язык. В 1939 г. по окончании школы и Юлиан Владимирович поступил учиться в МГУ, однако не на исторический, а на физический факультет, но был призван в армию: в этом году отсрочка для студентов была отменена. Великую Отечественную войну он встретил в действующей армии и прошел в ее составе весь путь до Победы. А вот по окончании войны он поступил на учебу уже на истфак МГУ, который закончил в 1950 г. Во время учебы специализировался по истории южных и западных славян, и по окончании МГУ был принят на работу в Институт славяноведения АН СССР. В 1952 г. перешел на работу в Отделение истории Академии наук. В 1956 г. защитил кандидатскую диссертацию, а в 1965-м докторскую. Обе работы были посвящены средневековой истории Хорватии. А в 1966 г. Ю.В. Бромлей был назначен директором Института этнографии АН СССР им. Н.Н. Миклухо-Маклая, и проработал в этой должности до 1989 г. В том же 1966 г. он был избран членом-корреспондентом АН СССР, а в 1976 г. действительным членом Академии.

Вероятно, для многих этнографов назначение Ю.В. Бромлея, историка, непосредственно с наукой о народах как бы не связанного, стало неожиданным. Какими в данном случае соображениями руководствовалось академическое начальство, не вполне понятно. Мне, однако, представляется, что приход руководителя академической этнографии как бы «со стороны» имел свои плюсы. Эта наука в России, располагая богатейшим и разнообразнейшим многоэтничным полем, еще до Октябрьской революции имела несомненные достижения в изучении этнического состава страны, быта и культуры ее народов, и успела накопить большой материал. Были разработаны не только методики сбора данных о быте народов, но и принципы их анализа. С другой же стороны, главным объектом изучения оставались все же традиционные доиндустриальные формы материальной и духовной культуры и быта. И именно это воспринималось этнографами как главный предмет исследования, тем более в ус- 
ловиях, когда доиндустриальные формы еще не были изжиты и даже, несмотря на несомненные изменения, во многом устойчиво продолжали воспроизводиться.

После же революции 1917 г. существенные перемены традиционного быта населения страны захватили не только повседневную сферу, но все без исключения стороны хозяйства и общественной жизни, включая науку, ее организацию и, особенно, идеологическую составляющую. После бурных дискуссий и споров о марксистском взгляде на историю, и соответственно о месте и значении науки о народах (Соловей 1998), в особенности роли в изучении их «нового социалистического быта», на какое-то время за этнографией в целом как бы сохранялась ее традиционная «ниша» исследования и описания этногенеза, «доисторических» социальных форм и доиндустриальных вариантов бытия.

Однако проблема необходимости изучения также и современных изменений в организации жизни и в быту оставалась задачей, стоявшей на повестке дня этнографии. Особенно это стало очевидно после завершения Великой Отечественной войны. Об этом, в частности, неоднократно заявлялось в статьях и выступлениях директора Института этнографии (с 1942 г.) С.П. Толстова (Толстов 1946; 1950; 1954; Толстов, Жданко 1964). И призывы не оставались только призывами: появилось немало публикаций, посвященных современному быту рабочих или колхозного крестьянства каких-либо конкретных поселений или отраслей промышленности. Но когда такие описания касались традиционного быта, в котором весь бытовой антураж, да и фольклорные жанры и представления о мире производились и воспроизводились в основном в узко локальной среде, передавались личностным путем, а потому имели очевидную этнокультурную специфику, накопление материалов подобного характера еще имело смысл. Иное дело в эпоху индустриализации, когда большинство бытовых аксессуаров становились покупными изделиями промышленного производства, касалось ли это одежды, мебели и убранства жилища, да и самой строительной техники и архитектуры жилых домов, бытовой утвари и т.д. И когда этнографы старыми методами скрупулезно фиксировали внедренные в народный быт промышленных форм, описывали соответствующие бытовые новации, это стало порой вызывать откровенные насмешки со стороны представителей смежных наук. Вопрос об изучении современности оставался открытым.

Понимали ли сами отечественные специалисты необходимость поиска и выработки новых подходов? Несомненно, да. Сошлюсь на классический и до сих пор не потерявший своей актуальности знаменитый учебник С.А. Токарева «Этнография народов СССР. Исторические основы быта и культуры» 1958 года издания. Во вводных разделах книги («От автора» и «Введение. 1. Предмет и метод этнографии как науки») С.А. Токарев, один из наших авторитетнейших специалистов XX века, достаточно ясно и подробно высказался о том, чем занимается этнография и какие проблемы перед ней стоят. Вот довольно подробная цитата на эту тему: «Наиболее заметные, прямо зияющие пробелы в этнографической изученности народов Советского Союза касаются их современного социалистического быта. Правда, чисто фактический, описательный материал по современному быту народов у нас накоплен, он продолжает накопляться через ежегодные специальные экспедиции, через местную и центральную прессу, литературу, через выставки и документальные кинофильмы. Но ведь одно дело - фактический чисто описательный материал, другое дело - его научное этнографическое исследование. С последним у нас дело обстоит еще очень неудовлетворительно: не 
сформулированы еще с должной отчетливостью проблемы этнографического изучения современности, нет еще основанных на серьезном анализе конкретного материала обобщений, строго научных выводов». И далее: «Подвергнуть этот быт сам по себе, его специфические особенности этнографическому изучению наша наука еще не сумела» (Токарев 1958: 4). Во Введении автор перечисляет 7 основных задач, стоящих перед этнографией, и среди них две (№ 3 и № 6) также касаются этнического и национального развития в современную эпоху и изучения перестройки народного быта, происходящей в наши дни (Токарев 1958: 9).

Итак, изучение этнографической современности было отчетливо понимаемой одной из первоочередных задач отечественной этнологии середины прошлого века. Но оставалась не разработанной проблема методики и даже самого исследовательского фокуса такого изучения.

Другая, отчасти связанная с первой, и не менее важная проблема, о которой до поры до времени говорить было не вполне возможным, заключалась в понимании и определении места главного объекта науки этнографии, то есть этноса, в классификации типов этнических и социальных общностей народов мира. Здесь голос профессиональных этнологов фактически не был слышен. Приоритет в определении этих форм социальной жизни остался за специалистами в области исторического материализма, прочно увязавшими типы этнических общностей с формулой «племя - народность - нация» и их обязательным соответствием формационной теории марксизма, по которой племя было формой первобытного доклассового общества, народность - рабовладения и феодализма, а нация капитализма и социализма. Обсуждение же этих сюжетов было невозможным, пока незыблемым оставалось сталинское определение нации как этнического образования, данное еще в 1913 г. Оно строилось на четырех признаках (общность территории, экономики, языка и психического склада, проявляющегося в общности культуры), без наличия любого из которых существование нации, по И.В. Сталину, невозможно (Сталин 1946: 296). Механистичность такого подхода поставила этнографов по отношению к современным этносам XX в. в ситуацию некоего прокрустова ложа. Если нация есть высший тип этнической общности, то любой народ при отсутствии одного из признаков, следовательно, не был нацией, то есть этнической общностью, или этносом. Существование множества фактов в жизни народов мира, когда, например, миграция нарушала общность территории, причем мигрировавшая часть народа сохраняла четкое сознание принадлежности к нему, соответственно заводило специалистов в понятийно-терминологический тупик.

В 1960-е годы, с началом «оттепели», наступило время некоторого обновления в сфере ряда до того «неприкасаемых» идеологических постулатов и их руководящего воздействия на науку. Одним из его проявлений в частности стала развернувшаяся на страницах нескольких солидных научных журналов («Вопросы истории», «Вопросы философии», «Народы Азии и Африки», «Советская этнография», «Советское государство и право») дискуссия по национальному вопросу. В ней приняли активное участие историки, философы, филологи, этнографы ${ }^{1}$, экономисты, юристы, представлявшие почти все национальные республики Союза. Было высказано немало интересных

${ }^{1}$ Из этнографов в дискуссии участвовали, например, С.А. Токарев, В.И. Козлов, Б.В. Андрианов, Л.П. Лашук, П.И. Пучков и другие (Токарев 1964; Андрианов 1967, Козлов 1967, 1968; Лашук 1967; Пучков 1968). 
суждений и мыслей о природе и функциях этнических и национальных явлений. В том числе детально был проанализирован каждый признак из сталинского определения нации, и по отношению к каждому высказывались достаточно аргументированные сомнения и возражения в части их всеобщнсти и универсальности. Однако, когда в 1970 г. подводились итоги дискуссии, авторы редакционной статьи «Вопросов истории» поступили довольно своеобразно. Они рассмотрели все «за» и «против» каждого признака нации из сталинского определения и методом простого подсчета каких высказываний больше вынесли заключение о том, что все перечисленные 4 признака нации остаются соответствующими сути явления (К итогам дискуссии... 1970: 8698). Таким образом, на идеологическом и на научном уровнях серьезных изменений в понятийно-терминологическом отношении формально как бы и не произошло. Но определенный импульс к дальнейшим научным поискам был все же очевиден.

Именно в такое время, когда обновление научного арсенала этнологии с очевидностью назрело, Юлиан Владимирович и возглавил академический институт этнографии. Да, он не был этнографом. Но работа в отделении истории Академии наук СССР «по определению» сделала его историком широкого профиля, которому было необходимо разбираться в самых разнообразных сферах этой по специфике своей необъятной области научного знания о человеческом пути развития. А некоторые плюсы отсутствия у нового директора опыта именно этнографической работы состояли, на мой взгляд, в том, что как раз вследствие этого он был свободен от сложившихся годами пристрастий и приверженности каким-либо прочно сформировавшимся научным интересам. Такие интересы, проявляясь и в некоей «инерции» профессиональных воззрений, несомненно, бывают у специалистов, долго работающих в русле сложившихся подходов и схем.

В составе института под руководством С.П. Толстова работала целая плеяда блестящих специалистов, заслугой которых можно считать и создание принципов этнографических классификаций (концепция хозяйственно-культурных типов и историко-этнографических областей), и подготовку уникального для того времени 18-томного издания «Народы мира», и участие в разработке системы этнографического образования, и многое другое. Издание серии томов «Народы мира» само по себе мобилизовало усилия большого коллектива ученых академических институтов Москвы, Ленинграда, союзных республик, оно стало настоящим событием в отечественной этнографии. Вместе с тем, такое энциклопедически масштабное издание не могло не выявить области профессионального знания о народах, которые нуждаются в совершенствовании. Например, в рецензии на завершающуюся серию были справедливо отмечены такие серьезные задачи, как необходимость пересмотра триады «племя - народность - нация» в качестве типов этнической общности, как назревшая необходимость исследования современности, включая этническое/национальное самосознание, этническую психологию, идентичность, как внедрение и использование полевых социологических исследований и углубление синтеза этнографии со смежными науками - археологией, антропологией, историей, социологией, языкознанием (Лашук 1966: 154, 155).

Но отчетливое понимание необходимости обновления и реализация такового поворота в науке - это далеко не одно и тоже. И в данном отношении отсутствие устоявшихся связей и приверженностей у нового руководителя академической науки как-то, возможно, помогло в деле осмысления и реализации актуальных задач. Во- 
лей-неволей ему нужно было оценить и взвесить полученное «наследие» и решить, как с ним жить и действовать дальше, и при этом не нанести вреда богатому наработанному предшественниками своду этнографических знаний и методам работы. Тем более, что многие из классиков отечественной науки были живы и продолжали активно работать. Несомненно, на опыт когорты корифеев, их знания, их советы новому директору тоже нужно было опереться в своей работе. И спустя более половины столетия есть основания в очередной раз взвесить, насколько это ему удалось. С такой точки зрения и следует, на мой взгляд, оценивать личный вклад Ю.В. Бромлея и место «бромлеевского периода» в истории нашей науки.

Одной из таких насущных проблем было, как отмечено выше, изучение этнографической современности. Но, сколько бы этнографы не спорили и не рассуждали о том, как ее изучать, было понятно, что сама действительность настолько изменилось, что традиционными методами ее фиксировать и исследовать вообще невозможно. И решение проблемы было предложено для того времени совершенно новаторское: в Институт этнографии были приглашены на работу исследователи, имевшие опыт социологических массовых опросов - Ю.В. Арутюнян и О.И. Шкаратан. По инициативе Ю.В. Бромлея был создан «Сектор конкретно-социологических исследований культуры и быта народов СССР», который возглавил Ю.В. Арутюнян. В его штат были приняты молодые выпускники ВУЗов, не только этнографы (их поначалу было меньшинство), но и историки, философы, даже математики и физики (Этносоциология 2008: 315-367). Молодому коллективу предстояло приступить к масштабным опросам населения разных национальных республик страны, с последующей сложной по тем временам процедурой обработки анкет и компьютерным подсчетом результатов. Этнографы таким опытом тогда не обладали.

Появление нового подразделения академического института, специально созданного для изучения национальных процессов с использованием социологического инструментария, для большинства сотрудников Института этнографии было, конечно, весьма непривычным. К этому подразделению долго с недоверием и настороженностью присматривались. Мне, закончившему кафедру этнографии МГУ и поступившему в ее аспирантуру, в те годы нередко приходилось бывать в институте и встречаться с коллегами-этнографами. Хорошо помню ту атмосферу несколько ироничного ожидания результатов работы этносоциологов: «Ну-ну, посмотрим, что они там наанкетировали...». С некоторыми из сотрудников нового сектора я был хорошо знаком, и поначалу казалось, что они и сами еще не очень верили в возможности новых методов. Начальству приходилось подробно объяснять научному сообществу смысл и перспективы применения социологии в этнографии. (Бромлей, Шкаратан 1969). Этносоциологи же, начав с обследования населения Татарской АССР, продолжили работу уже на уровне ряда союзных республик. Материал о современных этнонациональных процессах рос и расширялся.

В разработке научной концепции и инструментария опросов ведущую роль сыграли руководители проекта Ю.В. Арутюнян, О.И. Шкаратан, а затем М.Н. Губогло, Л.М. Дробижева, В.С. Кондратьев, А.А. Сусоколов и другие. Однако личный вклад в организацию и развертывание массовых исследований национальных процессов директора института, несомненно, был не менее значимым. Без его авторитета и организационной подготовки весь проект едва ли стал бы возможен: в советское время на это необходимо было получить одобрение союзных партийных и советских орга- 
нов, которые соответственно спускали директиву на республиканский уровень. Это обеспечивало необходимую поддержку и помощь на местах. Хотя, с другой стороны, пристальное внимание местных властей (бесспорно, несколько опасавшихся, как бы москвичи не «раскопали» чего-то лишнего) порой тоже мешало нормальной работе. Понимание ситуации соответственно побуждало и самих исследователей к определенной «самоцензуре» (Савоскул 2008: 320-325).

Если же задаться вопросом о том, решило ли появление и развитие этносоциологии все проблемы исследования этнических процессов современности, то однозначно ответить на него трудно. Конечно, это был прорыв в научном понимании структуры и динамики национальных отношений в стране. Разумеется, весь спектр сложнейшей сферы этнического взаимодействия, тем более его места в структуре социальных связей в масштабе советского общества, охватить и отразить было весьма сложно. Так как меня мой учитель Л.П. Лашук ориентировал как раз на внедрение в этнографию социологических методов работы, я внимательно следил за исследованиями коллег-этносоциологов. Должен признаться, что при знакомстве с их результатами меня долго не покидало впечатление, что идет простое накопление материала о социально-профессиональном составе населения в национальном разрезе. При этом еще оставалось смутное ощущение, что чего-то здесь не хватает, а к пониманию чего именно я подошел только постепенно: не хватало картины того, как идентификация этническая сочетается с другими социальными идентичностями и в каком иерархическом соотношении они находятся друг с другом.

По опыту своего участия в нескольких массовых опросах в разных регионах страны могу сказать, что анкетные методы мне как этнографу, привыкшему к свободной по форме этнографической информации, сначала не очень нравились. Но я довольно быстро понял их ценность и полезность. Во-первых, практически всегда можно было после анкетного опроса поговорить с респондентом о том, что тебя интересует, «без анкеты». Главная же польза открылась в том, что обобщенный материал опроса нередко высвечивал совершенно иную картину по сюжетам, которые до этого априорно представлялись как бы ясными совсем по-другому. А это всегда стимулировало на дальнейший поиск объяснения и анализ.

В итоге, когда наши коллеги собрали материал своих исследований в сводный том, значительность и ценность полученных ими данных стала очевидна (Социально-культурный облик: 1986). Конечно, авторы и сами продолжали искать и совершенствовать методы и инструментарий, при этом вполне лояльно относясь к опытам коллег. Я, например, до сих пор благодарен за ту совершенно бескорыстную помощь в организации своих экспедиций и за разрешение использования созданного институтскими коллегами инструментария со стороны Л.М. Дробижевой и покойных коллег В.С. Кондратьева и А.А. Сусоколова, а также за их корректное и доброжелательное отношение к нашим «добавлениям и вариациям» к их базовому вопроснику.

Таким образом, социологические методы в этнографии - несомненная и бесспорная заслуга и лично Ю.В. Бромлея с коллегами, и в целом всего «бромлеевского периода» в нашей науке. Сейчас эти методы прочно вошли в арсенал антрополого-этнологических исследований, хотя ныне по понятным обстоятельствам они не достигают масштабов того времени. Однако в наши дни этнологи редко обходятся в изучении современности без отработанных ранее методик, расширяя и совершенствуя приемы работы. Немаловажно и то, что многие исследователи из националь- 
ных районов, пройдя школу в виде стажировки или аспирантуры в секторе этносоциологии ИЭА, стали серьезными самостоятельными учеными. Это тоже следствие большой организационной работы, проделанной институтом в 1960-1980-е годы (Этносоциология вчера и сегодня 2016: 77-145).

Параллельно с организацией этнологического изучения современных этнических процессов в стране Ю.В. Бромлей занимался разработкой теоретико-методологического арсенала науки о народах. Речь не шла о тотальной ревизии наработок предшественников, однако этнография остро нуждалась в уточнении самого основного предмета изучения, включая составляющие его базовые понятия, прежде всего этнос как явление и феномен бытия человечества. Несомненно, для этого директору института необходимо было прежде всего разобраться и осмыслить комплекс проблем науки для себя, а затем изложить это свое понимание научному сообществу. На это хотя и ушло несколько лет, но уже в 1973 г. Юлиан Владимирович издал одну из своих основных книг, где была изложена его теория этноса, получившая название дуальной или бинарной (Бромлей 1973; 1983).

Кроме того, что с этих пор этнос надолго стал основным объектом изучения для науки о народах, значение бинарной теории заключалось в том, что произошел хотя еще и не полный, но все же очень важный частичный уход от догматики механистических определений с обязательными и неизменными наборами признаков. Бромлей показал, что этнос на самом деле характеризуется разными признаками и структурными компонентами, среди которых могут быть такие объединяющие носителей этнической идентичности компоненты, как язык и культура, а могут преобладать сложные скрепы социально-организационного уровня. Первый тип общности автор назвал этникос (прилагательное от греческого слова этнос, т. е. этнический), а второй этносоциальный организм (ЭСО). Второй тип общности, таким образом, характеризовался более широкими основаниями социально-экономических, территориальных, государственно-политических коммуникаций. Это давало возможность вести речь об узком значении понятия этнос (этникос) и более широком спектре социальных связей (ЭСО), то есть изучать одно и то же явление (этнос) под несколько разными, узким и более расширенным, углами зрения.

Бинарная или дуальная теория этноса была принята научным сообществом и многими коллегами разделялась. Во всяком случае она позволила уйти от связывающего научный поиск обязательного и неизменного набора признаков объекта, показала объект сложным явлением, динамичным и подверженным изменениям. В данном отношении она была шагом вперед в развитии этнологической мысли. В частности, предложенное понимание этноса позволило наконец снять очевидное противоречие в отношении многих народов, разделенных государственными границами и лишенных общей этнической территории.

Важно отметить и то, что как глава отечественной этнографии Ю.В. Бромлей отнюдь не считал себя теоретическим монополистом и вполне благосклонно относился к появлению иных теоретических концепций, предлагаемых своими подчиненными, например, к информационной теории этноса С.А. Арутюнова и Н.Н. Чебоксарова, или к компонентной теории В.В. Пименова (Арутюнов, Чебоксаров 1972; Пименов 1977).

Можно сказать, что бинарная теория, став частичным отходом от жестких дефиниций явления, показала сложность изучаемых наукой национальных процессов. С позиций сегодняшнего дня ей, конечно, тоже можно предъявить ряд претензий. Например, то, что в части понимания связи этнического фактора с системой современ- 
ных социальных отношений она сохраняла советскую традицию этнизации понятия нации, свойственную еще сталинскому определению. При этом научному сообществу было хорошо известно, что в англо-французской литературе давно преобладало не этническое, а этатистское понимание термина и сущности нации, высказанное еще в годы французской революции аббатом Сиейесом: «Совокупность объединенных индивидуумов, живущих под общим законом и представляемых одними и теми же законодательными органами» (Sieyes 1888: 31).

Такое понимание феномена нации необходимо было разрабатывать в нашей науке потому, в частности, что это помогло бы освободиться от неверного определения нации как «высшего типа этнической общности». Нация вообще не есть тип этнической общности, ее появление в эпоху модерна связано было с рождением принципиально нового (в сравнении с доиндустриальным этносом) способа адаптации в среде обитания, построенного на дифференцированных видах деятельности уже не на этнической, а на профессиональной основе. И если в начальный период становления нового способа адаптации в среде обитания дифференциация деятельности и происходила в какой-либо моноэтнической среде, то очень быстро расширение обменных связей начинало захватывать и интегрировать в нацию иноэтничные группы в границах государства. На эту тему в свое время очень точно высказался Х. Ортега-и-Гассет, заметив, что входящие в государство этносы еще могли бы существовать по отдельности, в отличие же от них все социально-профессиональные группы нации принципиально не могут существовать друг без друга (Opmeza-u-Гасcem 1994: 47-48). Только вместе они способны заменить прежний этнически специфичный способ адаптации в среде обитания на новый, через набор необходимых для воспроизводства социума профессионально, а не этнически специализированных видов деятельности, уже не строго зависимых от этнической принадлежности их представителей. Это и есть совокупное сообщество людей, составляющее нацию.

В свете высказанных соображений следовало бы несколько скорректировать сущностное содержание термина ЭСО: речь здесь не столько об этно-социиальном организме - частица «этно» возвращает нас к понятию этно-нации и нации как якобы высшем типе этнической общности. Следовательно, для понимания организационных начал современного этноса точнее будет не термин этносоциальный организм, а определение места и функций того или иного этноса, входящего в состав нации, в системе ее социально-воспроизводственных связей.

Так как базовые основания, на которых выделяются этнос в узком смысле (этникос) и ЭСО, различны, то из этого вытекает еще одно существенное отличие выделенных форм бытия этноса. Когда общность скрепляют такие явления как язык и культурная специфика, то эта форма общности есть феномен, имеющий диахронную природу. В отличие от него, когда в основе ЭСО лежат социально-воспроизводственные механизмы, объединяющие нацию и этносы в ее составе, эта связь имеет синхронную природу. Разрушение такого воспроизводственного единства структуры нации неизбежно повлечет за собой деструкцию самого явления, включая место в нем входящих в нацию народов.

Из сказанного вытекает, что появление бинарной теории этноса стало несомненным шагом вперед в развитии этнологической мысли уже потому, что данная теория определенно показала: этнос есть явление подвижное и способное строиться на базе различных и варьирующих связей. К слову, впервые мысль о том, что понятие этнической общности следует определять именно по связям, которые общность 
скрепляют, а не по признакам, была высказана С.А. Токаревым (Токарев 1964: 43). Мысль в сущности элементарно простая, а потому верная, ибо любую общность как явление скрепляет ничто иное как та или иная связь или группа связей. Строгое следование данной линии непременно привело бы и к пониманию того, что нация не тип этнической общности, а также к ясному представлению о природе сходства и различия между этносом и нацией как видами общности. Но это уже был бы следующий шаг, а первый был все же сделан.

Кроме разработки теории этноса в заслугу Ю.В. Бромлею следует поставить также то, что в трудах его и его коллег по институту в те годы закрепилось понимание этноса как живого и развивающегося явления и перманентного процесса. Постоянное внимание к этническим процессам, стремление к отслеживанию изменений - очевидное достижение «бромлеевского периода» не только в работе ИЭА, но и всей советской этнографии тех лет. Не случайно коллективная монография о современных этнических процессах в СССР, вышедшая под редакцией Ю.В. Бромлея двумя изданиями, была заслуженно удостоена Государственной премии СССР (Современные... 1975; 1977). А в 1987 г. институт подготовил и опубликовал работу об этнических процессах в современном мире, в которой Ю.В. Бромлей стал не только ответственным редактором, но и автором трети разделов книги (Этнические процессы 1987).

Необходимо отметить, что помимо разработки теории этноса Ю.В. Бромлей много полезного сделал для категоризации системы понятий в нашей этнологии. Здесь можно назвать и представление о типах этнических процессов (подразделение на этноэволюционные и этнотрансформационные, интегративные и этноразделительные), и четкое объяснение различия между понятиями «этническая группа» и «этнографическая группа». Под первой понимается часть народа, оказавшаяся отделившейся по тем или иным причинам от основного этнического массива и живущая в иноэтничном окружении, под второй же совокупность людей, имеющая какие-либо особенности культуры и быта и по этим признакам выделяемая специалистами-этнографами (Бромлей, Козлов 1987: 5-30). Все это вместе способствовало утверждению в те годы термина «этнос» в науке о народах и в широких границах общественного дискурса, в системе образования, и довольно четкому представлению общества о природе этнического и этнических процессах в их динамике.

К плодотворным усилиям Юлиана Владимировича по части категоризации научного этнологического знания относится также подготовленная в 1986-1995 годы по его инициативе совместно с коллегами из ГДР серия справочного характера «Свод этнографических понятий и терминов» из шести выпусков (Свод этнографических 1986-1995). Бромлей был главой редколлегии серии, но выпуски 3-6 увидели свет уже после его кончины.

Характеристика «бромлеевского периода» советской этнологии была бы неполной, если не упомянуть о том, что с ним связано заметное расширение предметного поля этнографии/этнологии, развертывание таких направлений исследований, как этноэкология (В.И. Козлов), этнопсихология (И.С. Кон), этнодемография (П.И. Пучков и О.Е. Казьмина), а затем и медицинская антропология (В.И. Харитонова). И здесь можно вести речь не просто о расширении диапазона исследований, но об отчетливом понимании объективного роста связей этнического аспекта бытия с широким спектром социальных взаимодействий. И это тоже показатель широты взглядов директора Института этнографии на предметное поле науки. 
В заключение выскажу свои впечатления о Бромлее-человеке. Мне не довелось, к сожалению, ни часто, ни близко с ним общаться, хотя в период, когда он преподавал на кафедре этнографии МГУ в 1970-е-1980-е годы, встречаться с ним приходилось, также как на различных этнографических конференциях разного уровня. Этого общения было достаточно, чтобы вынести суждение: это был глубоко интеллигентный и очень доброжелательный и демократичный человек. К коллегам по кафедре, включая молодежь, он относился очень по-доброму и поддерживал молодых этнографов насколько мог. Я, например, был свидетелем того, как Юлиан Владимирович однажды пришел на кафедру и принес только вышедшую монографию А.А. Никишенкова о британском функционализме, с которой он познакомился (Никишенков 1986). Книга была подготовлена на основе кандидатской диссертации автора. Однако Бромлей уверенно заявил: «Ему (автору -В.К.) надо ее как докторскую защищать». Мне точно известно, что это предложение он повторил не однажды. Думаю, не так много нашлось бы коллег, кто устоял бы перед соблазном откликнуться на предложение академика. Но не Алексей Алексеевич, который потратил еще 20 лет, пока не довел работу до уровня, который, по его представлению, соответствовал докторской. Были у Ю.В. Бромлея и аспиранты по кафедре, с которыми он вполне ответственно работал и доводил до защиты.

Итог. Приход Юлиана Владимировича в этнографию открыл, на мой взгляд, довольно плодотворный период в развитии науки. Несомненно, в этом был очевидный личный вклад Бромлея как ученого и как организатора науки. Став директором академического института, он достаточно глубоко погрузился в актуальные проблемы, стоявшие перед этнографией, и при этом вполне оперативно их если не полностью решил, то весьма серьезно поспособствовал решению. Это и отмеченный выше теоретический сдвиг в представлениях о природе этноса, и существенные подвижки в способах и приемах изучения этнографической современности. Научная общественность и общественное сознание получили достаточно ясное и подробное представление о феномене этноса и системе этнических категорий. Если бы комплекс данных наработок стал основой дальнейшей углубленной исследовательской деятельности этнологов, можно предположить, что это смогло бы принести большую пользу. Но с 1990-х гг. произошла резкая смена парадигмы и отход от этнологического взгляда на развитие и бытие народов в пользу конструктивизма. А параллельно тотальная антропологизация этнологии временами стала оборачиваться утерей профессионального видения предмета.

Я никоим образом не против внедрения социально-антропологических подходов, и вижу немалую пользу в их применении к разнообразным ситуациям и явлениям современного мира. Но в сочетании с типичным для постмодерна избеганием обобщений и категоризации (без которых наука уже и не вполне наука) - все это способствует отходу от этнологического видения и размыванию предметного поля. А что касается отношения к этносу как лишь результату конструирования и общности якобы виртуальной - это ведь тоже результат определенной общей нашей недоработки в части онтологического понимания специфики феномена «этнос» и причинах изменения функций этноса в эпоху модерна.

Несколько упрощая, конечно, причины рождения конструктивизма, полагаю, что ситуация, когда видимых проявлений этнического и этничности в обществе модерна становится все меньше, мнение о том, что, следовательно, этнос категория искус- 
ственная, просто стало явным упрощением подхода к постижению сути явления. Ведь формирование представлений об этносе в эпоху модерна стало тоже профессиональной функцией (в частности политиков и идеологов), подобно всякой иной профессионализации деятельности. И в этом конструктивисты правы: социальное воздействие на массу действительно весьма выросло, будучи специализированной функцией профессионалов-идеологов. Но ведь из этого вовсе не следует вывод, что этнос понятие иллюзорное. Оно реально, но его прежние функции, несомненно, изменились. И если бы линия, выработанная Ю.В. Бромлеем и коллегами, продолжала развиваться и углубляться, наука этнология вполне была бы в состоянии это адекватно объяснить. Таким образом, «бромлеевский период» и личный вклад Бромлея в нашу науку бесспорно можно считать одним из самых продуктивных периодов в истории отечественной этнологии. Впрочем, «по большому счету» условия для его более глубокого анализа пока не созрели. Но, надеюсь, такое время еще придет.

\section{Научная литература}

Андрианов Б.В. Проблемы формирования народностей и наций в странах Африки // Вопросы истории, 1967. № 9. С. 101-114.

Арутюнян Ю.В., Ю.В. Бромлей Ю.В. (под ред.). Социально-культурный облик советских наций. По материалам этносоциологического исследования. М.: Наука, 1986. 453 с.

Арутюнов С.А., Чебоксаров Н.Н. Передача информации как механизм существования этносоциальных и биологических групп // Расы и народы, 1972. № 2. С. 8-30.

Бромлей Ю.В. Этнос и этнография. М.: Наука, 1973. 283 с.

Бромлей Ю.В. Очерки теории этноса. М.: Наука, 1983. 418 с.

Бромлей Ю.В., Козлов В.И. Этносы и этнические процессы как предмет исследования // Этнические процессы в современном мире. М.: Наука, 1987. С. 5-30.

Бромлей Ю.В., Шкаратан О.И. О соотношении истории, этнографии и социологии // Советская этнография. 1969. № 3. С. 3-19.

Бромлей Ю.В. (отв. ред.). Современные этнические процессы в СССР. М.: Наука, 1975; 2-е изд. М.: Наука, 1977. 543 с.

Бромлей Ю.В. (отв. ред.). Этнические процессы в современном мире. М.: Наука, 1987. 446 с.

Бромлей Ю.В., Штробах Г. (ред.). Свод этнографических понятий и терминов. Вып. 1: Социально-экономические отношения и соционормативная культура. М.: Наука, 1986. 240 с.

Бромлей Ю.В., Штробах Г. (ред.). Свод... Вып. 2: Этнография и смежные дисциплины. Этнографические субдисциплины. Школы и направления. Методы. М: Наука, 1988. 225 с.

Бромлей Ю.В., Штробах Г. (ред.). Свод...Вып. 3. Материальная культура. М. «Наука» 1989. 224 с. Бромлей Ю.В., Штробах Г. (ред.). Свод... Вып. 4. Народные знания. Фольклор. Народное искусство. М.: «Наука», 1991. 166 с.

Бромлей Ю.В., Штробах Г. (ред.). Свод... Вып. 5. Религиозные верования. М.: Наука, 1993. 239 с.

Бромлей Ю.В., Вайнштейн С.И. (ред.). Свод... Вып. 6. Этнические и этно-социальные категории. М.: ИЭА РАН, 1995. 216 с.

Губогло М.Н. Аллюзии импрессионизма в этносоциологии // Вестник антропологии, 2016. № 2. C. 54-80.

Дубова Н.А., Остапенко Л.В., Субботина И.А. (сост.). Этносоциология и этносоциологи. Исследования, поиски, воспоминания. М.: Старый сад, 2008. 360 с.

К итогам дискуссии по некоторым проблемам теории нации // Вопросы истории, 1970. № 8. C. $86-98$.

Козлов В.И. Некоторые проблемы теории нации // Вопросы истории, 1967. № 1. С. 88-99.

Козлов В.И. Типы этнических процессов и особенности их исторического развития // Вопросы истории, 1968. № 9. С. 95-109. 
Лашук Л.П. Многотомная серия «Народы мира» и некоторые проблемы развития этнографии // Вопросы истории, 1966. № 10. С. 144-145.

Лашук Л.П. О формах докапиталистических этнических связей // Вопросы истории, 1967. № 4. С. 77-92.

Никишенков А.А. Из истории английской этнографии. Критика функционализма. М.: Изд-во МГУ, 1986. $213 \mathrm{c.}$

Ортега-и-Гассет Х. Этюды об Испании. Киев: Новый круг Пор-Рояль, 1994. 317 с.

Остапенко Л.В., Субботина И.А. (отв. ред.). Этносоциология вчера и сегодня. М.: ИЭА PAH, 2016. $474 \mathrm{c}$.

Пименов В.В. Удмурты. Опыт компонентного анализа этноса. М.; Л.: Наука, 1977. 262 с.

Пучков П.И. К анализу этнической ситуации в Океании // Вопросы истории, 1968. №10. С. 90-104.

Савоскул С.С. Из воспоминаний этносоциолога «второго призыва 1989 вып.» // Этносоциология и этносоциологи. Исследования, поиски, воспоминания. М.: Старый сад, 2008. С. 320-325.

Соловей Т.Д. От «буржуазной» этнологии к «советской» этнографии. История отечественной этнологии первой трети ХХ века. М.: ИЭА РАН, 1998. 258 с.

Сталин И.В. Марксизм и национальный вопрос. Соч. Т. 2. М. 1946. С. 290-367.

Тишков B.A. Откуда и куда пришла российская этнология. Персональный взгляд в глобальной перспективе // Этнографическое обозрение, 2020. № 2. С. 72-137.

Токарев С.А. Этнография народов СССР. Исторические основы быта и культуры. М.: Изд-во МГУ, 1958. $616 \mathrm{c.}$

Токарев С.А. Проблема типов этнических общностей (к методологическим проблемам этнографии) // Вопросы философии, 1964. № 11. С. 43-53.

Толстов С.П. Этнография и современность // Советская этнография, 1946. № 1. С. 3-11.

Толстов С.П. Основные задачи и пути развития советской этнографии // Краткие сообщения Института этнографии. Вып. 12. 1950. С. 5-14.

Толстов С.П. Задачи советской этнографии // Вопросы истории, 1954. № 11. С. 160-163.

Толстов С.П., Жданко Т.А. Пути развития и проблемы советской этнографии // Вопросы истории, 1964. № 7. С. 3-20.

Чешко С.В. О творческом наследии Ю.В. Бромлея // Вестник антропологии, 2016. № 2. С. 6-24. Sieyes E. Qu'est-ce que le tiers etat? // Societe de l'Histoire de la Revolution Francaise. Paris, 1888. P. 31.

Karlov, Victor $V$.*

\section{Yulian V. Bromley and the "Bromley Period" in Russian Ethnology}

DOI: $10.33876 / 2311-0546 / 2021-53-1 / 9-23$

The article is devoted to the $100^{\text {th }}$ anniversary of Yu. V. Bromley, who headed the academic Institute of Ethnography for more than 20 years. In order to assess the period in the history of Russian ethnology, when its development was led by Yu. V. Bromley, the author analyses ethnographic science and the priority tasks it was facing at the time when Bromley became the Director of the Institute. These were, first of all, problems of studying ethnographic modernity, as well as the need to update the theoretical base of ethnography. The leading ethnographers acknowledged the seriousness and scale of these tasks, but the methods for solving them were not developed. The article assesses the contribution the academician made to the development of science in the USSR, as well as the entire period of 1960-80 in Russian ethnology. The article analyzes the theory of ethnos proposed by Yu. V. Bromley, the development of the categorical apparatus of ethnological science and methods for the study of ethnographic modernity. During the leadership of Yu. V. Bromley, the Institute of Ethnography introduced serious and positive changes in these areas of ethnological knowledge. The author argues that that was a very fruitful period in the history of ethnological knowledge in the USSR. 
Keywords: Yu. V. Bromley, theory of ethnos, ethnography of modernity, history of ethnology

For Citation: Karlov, V.V. 2021. Yulian V. Bromley and the "Bromley Period" of the Russian Ethnology . Herald of Anthropology (Vestnik Antropologii) 1 (53): 9-23.

*Karlov, Victor V.- Dr. (Hist.), Prof., Lomonosov Moscow State University (119991 Moscow, Lomonosov prosp., 27). E-mail: vikarlov@mail.ru

\section{References}

Andrianov, B.V. 1967. Problemy formirovaniia narodnostei i natsii v stranakh Afriki [Problems of the formation of nationalities and nations in the countries of Afrika] Voprosy istorii 9: 101-114.

Arutiunian, Iu.V., Iu.V. Bromlei Iu.V. (ed.). 1986. Sotsial'no-kul'turnyi oblik sovetskikh natsii. Po materialam etnosotsiologicheskogo issledovaniia [Socio-cultural image of the Soviet nations. Based on the materials of ethnosociological research]. Moscow: Nauka.

Arutiunov, S.A., Cheboksarov N.N. 1972. Peredacha informatsii kak mekhanizm sushchestvovaniia etnosotsial'nykh i biologicheskikh grupp [Information transmission as a mechanism for the existence of ethnosocial and biological groups]. Rasy i narody 2: 8-30.

Bromlei, Iu.V. 1973. Etnos i etnografiia [Ethnos and ethnography]. Moscow: Nauka.

Bromlei Iu.V. and V.I. Kozlov 1987. Etnosy i etnicheskie protsessy kak predmet issledovaniia [Ethnoses and ethnic processes as a subject of research]. In Etnicheskie protsessy v sovremennom mire [Ethnic processes in a contemporary world], 5-30. Moscow: Nauka.

Bromlei, Iu.V. and O.I. Shkaratan. 1969. Sootnoshenii istorii, etnografii i sotsiologii [On the correlation of history, ethnography and sociology]. Sovetskaia etnografiia 3: 3-19.

Bromlei, Iu.V. (ed.). 1975, 1977. Sovremennye etnicheskie protsessy v SSSR [Modern ethnic processes in the USSR]. Moscow: Nauka.

Bromlei, Iu.V. (ed.). 1987. Etnicheskie protsessy v sovremennom mire [Ethnic processes in the modern world]. Moscow: Nauka.

Bromlei, Iu.V. and G. Shtrobakh(ed.). 1986. Svod etnograficheskikh poniatii i terminov. Vyp.1: Sotsial'noekonomicheskie otnosheniia i sotsionormativnaia kul tura [A set of ethnographic concepts and terms. Vol. 1: Socio-economic relations and socionormative culture]. Moscow: Nauka.

Bromlei, Iu.V. and G. Shtrobakh (ed.). 1988. Svod... Vyp. 2: Etnografiia i smezhnye distsipliny. Etnograficheskie subdistsipliny. Shkoly i napravleniia. Metody [A set... Vol. 2: Ethnography and related disciplines. Ethnographic sub-disciplines. Schools and destinations. Methods]. Moscow: Nauka.

Bromlei, Iu.V. and G. Shtrobakh (ed.). 1989. Svod...Vyp. 3. Material'naia kul'tura [A set... Vol. 3. Material culture]. Moscow: Nauka.

Bromlei, Iu.V. and G. Shtrobakh (ed.). 1991. Svod... Vyp. 4. Narodnye znaniia. Fol'klor. Narodnoe iskusstvo [A set... Vol. 4. The people of knowledge. Folklore. Folk art]. Moscow: Nauka.

Bromlei, Iu.V. and G. Shtrobakh (ed.). 1993. Svod... Vyp. 5. Religioznye verovaniia [A set... Vol. 5. Religious beliefs]. M.: Nauka, 1993.

Bromlei, Iu.V.and S.I. Vainshtein (red.). 1995. Svod... Vyp. 6. Etnicheskie i etno-sotsial'nye kategorii [A set... Vol. 6. Ethnic and ethno-social categories]. Moscow: Institute of ethnology and anthropology RAN.

Cheshko, S.V. 2016. O tvorcheskom nasledii Iu.V. Bromleia [About the creative heritage of Y. V. Bromley]. Vestnik antropologii 2: 6-24.

Dubova, N.A., L.V. Ostapenko and I.A. Subbotina (ed.). 2008. Etnosotsiologiia i etnosotsiologi. Issledovaniia, poiski, vospominaniia [Ethnosociology and ethnosociologists. Researches, searches, memories]. Moscow: Staryi sad.

Guboglo, M.N. 2016. Alliuzii impressionizma v etnosotsiologii [Allusions of impressionism in ethnosociology]. Vestnik antropologii 2: 54-80.

$\mathrm{K}$ itogam diskussii po nekotorym problemam teorii natsii [To the results of the discussion on some problems of the theory of the nation]. 1970. Voprosy istorii 8: 86-98. 
Kozlov, V.I. 1967. Nekotorye problemy teorii natsii [Some problems of the theory of the nation]. Voprosy istorii 1: 88-99.

Kozlov, V.I. 1968. Tipy etnicheskikh protsessov i osobennosti ikh istoricheskogo razvitiia. [Types of ethnic processes and features of their historical development]. Voprosy istorii 9: 95-109.

Lashuk, L.P. 1966. Mnogotomnaia seriia "Narody mira' i nekotorye problemy razvitiia etnografii [Multi-volume series "Peoples of the world" and some problems of ethnography development]. Voprosy istorii 10: 144-145.

Lashuk, L.P. 1967. O formakh dokapitalisticheskikh etnicheskikh sviazei [On the forms of precapitalist ethnic ties]. Voprosy istorii 4: 77-92.

Nikishenkov, A.A. 1986. Iz istorii angliiskoi etnografii. Kritika funktsionalizma [From the History of English Ethnography. Criticism of functionalism]. Moscow: Moscow State Universiry.

Ortega-i-Gasset, Kh. 1994. Etiudy ob Ispanii [Sketches of Spain]. Kiev: Novyi krug Por-Roial',

Ostapenko L.V., Subbotina I.A. (ed). 2016. Etnosotsiologiia vchera i segodnia [Ethnosociology yesterday and today]. Moscow: Institute of ethnology and anthropology RAN.

Pimenov, V.V. 1977. Udmurty. Opyt komponentnogo analiza etnosa [Udmurts. Experience of component analysis of an ethnic group]. Moscow-Leningrad: Nauka.

Puchkov, P.I. 1968. K analizu etnicheskoi situatsii v Okeanii Voprosy istorii [To analyze the ethnic situation in Oceania]. Voprosy istorii 10: 90-104.

Savoskul S.S. 2008. Iz vospominanii etnosotsiologa "vtorogo prizyva" [From the memoirs of an ethnosociologist of the "second draft] In Etnosotsiologiia i etnosotsiologi. Issledovaniia, poiski, vospominaniia. Moscow: Staryi sad. P. 320-325.

Solovei, T.D. 1998. Ot "burzhuaznoi” etnologii k "sovetskoi” etnografii. Istoriia otechestvennoi etnologii pervoi treti XX veka [From a "bourgeois" ethnology to a "soviet" ethnography. History of Russian ethnology of the first third of the twentieth century]. Moscow: Institute of ethnology and anthropology RAN.

Stalin, I.V. 1946. Marksizm i natsional'nyi vopros [Marxism and the national question]. Collected works. Vol. 2, 290-367. Moscow.

Tishkov, V.A. 2020. Otkuda i kuda prishla rossiiskaia etnologiia. Personal'nyi vzgliad v global'noi perspektive [Where and where Russian ethnology came from. A personal view from a global perspective]. Etnograficheskoe obozrenie 2: 72-137.

Tokarev, S.A. 1958. Etnografiia narodov SSSR. Istoricheskie osnovy byta i kul'tury [Ethnography of the peoples of the USSR. Historical foundations of everyday life and culture. Moscow: Lomonosov Moscow State University.

Tokarev, S.A. 1964. Problema tipov etnicheskikh obshchnostei (k metodologicheskim problemam etnografii) [The problem of types of ethnic Communities (on methodological problems of ethnography]. Voprosy filosofii 11: 43-53.

Tolstov S.P. 1946. Etnografiia i sovremennost [Ethnography and modernity]. Sovetskaia etnografiia 1:3-11.

Tolstov S.P. 1950. Osnovnye zadachi i puti razvitiia sovetskoi etnografii [The main tasks and ways of development of Soviet ethnography]. Kratkie soobshcheniia Instituta etnografii. 12: 5-14.

Tolstov, S.P. 1954. Zadachi sovetskoi etnografii [Tasks of Soviet ethnography]. Voprosy istorii 11: 160-163.

Tolstov, S.P. and T.A. Zhdanko. 1964. Puti razvitiia i problemy sovetskoi etnografii [Ways of development and problems of Soviet ethnography]. Voprosy istorii 7: 3-20. 